STUDIA Z PRAWA WYZNANIOWEGO

Tom $24-2021$

DOI: https://doi.org/10.31743/spw.12734

\title{
MECHANIZM LIMITACJI PRAWA DO WOLNOŚCI UZEWNĘTRZNIANIA PRZEKONAŃ RELIGIJNYCH W MIĘDZYNARODOWYM SYSTEMIE OCHRONY PRAW CZŁOWIEKA ZE SZCZEGÓLNYM UWZGLĘDNIENIEM KONTEKSTU EUROPEJSKIEGO
}

The mechanism of limiting the right to the freedom to manifest religious beliefs in the international system of human rights with a particular emphasis on the European context

Streszczenie: Artykuł 18 Powszechnej Deklaracji Praw Człowieka stanowi, że prawo do wolności myśli, sumienia i religii obejmuje (obok swobody zmiany religii i przekonań) prawo do uzewnętrzniania swojej religii lub przekonań. W budowanym po II wojnie światowej międzynarodowym systemie ochrony praw człowieka zadaniem Deklaracji było proklamowanie praw człowieka jako standardu międzynarodowego, a tym samym wskazanie podstawowych treści samego pojęcia praw człowieka użytego w Karcie Narodów Zjednoczonych. Analogiczne do treści art. 18 Deklaracji prawo do uzewnętrzniania przekonań religijnych uznane jest w art. 9 Konwencji o Ochronie Praw Człowieka i Podstawowych Wolności, art. 18 Międzynarodowego Paktu Praw Obywatelskich i Politycznych oraz w art. 10 Karty Praw Podstawowych Unii Europejskiej - traktatowych aktach normatywnych praw człowieka, mających znaczenie dla europejskiego rozumienia standardu ochrony w zakresie prawa do uzewnętrzniania religii lub przekonań na poziomie ponadpaństwowym i regionalnym. Ustępy drugie Konwencji i Paktu zawierają klauzule limitacyjne, dopuszczające ograniczenie wolności uzewnętrzniania przekonań religijnych. Karta przejmuje z Konwencji - choć nie bez zastrzeżeń - zakres chronionych praw, a przez to również mechanizmy limitacyjne.

* Ks. dr, Wydział Prawa i Administracji, Uniwersytet Szczeciński, ul. Gabriela Narutowicza 17A, 70-953 Szczecin, e-mail: maciej.kubala@usz.edu.pl. ORCID 0000-0001-5475-1334. 
W niniejszym opracowaniu zastosowano metodę dogmatyczno-prawną. Dążąc do przyczynienia się do lepszego rozumienia praktycznoprawnych konsekwencji realizacji teoretycznych założeń klauzul limitacyjnych $\mathrm{w}$ - istotnych z europejskiego punktu widzenia - przepisach traktatowych chroniących wolność uzewnętrzniania przekonań religijnych, Autor omawia odnośne przepisy Konwencji, Paktu i Karty, analizując warunki prawnej dopuszczalności limitacji prawa do uzewnętrzniania przekonań religijnych na gruncie omawianych aktów prawa międzynarodowego.

Słowa kluczowe: ograniczanie praw i wolności; system ochrony praw człowieka; wolność sumienia i religii; przekonania religijne; Karta Praw Podstawowych UE; Konwencja o Ochronie Praw Człowieka i Podstawowych Wolności

Abstract: Article 18 of the Universal Declaration of Human Rights provides that the right to the freedom of thought, conscience and religion (along with the freedom to change one's religion or belief) includes the right to manifest religious beliefs. In the international system of human rights protection built after the Second World War, the aim of the Declaration was to proclaim human rights as an international standard and consequently, to define the notion of human rights as used in the United Nations Charter. In parallel to Article 18 of the Declaration, the right to the freedom to manifest religious beliefs is recognized by Article 9 of the Convention for the Protection of Human Rights and Fundamental Freedoms, Article 18 of the International Covenant on Civil and Political Rights and Article 10 of the Charter of Fundamental Rights of the European Union - treaties concerning human rights, important for the European understanding of the standard of protection of the right to manifest religion or beliefs on the transnational and regional level. The second paragraphs of the Convention and the Covenant contain limitation clauses that permit the limitation of the freedom to manifest religious beliefs. The Charter draws - though not without reservations - from the Convention's protected rights, including limitation mechanisms. The analysis presented in this paper is conducted using the legal dogmatic method. In order to contribute to a better understanding of the practical and legal consequences of the implementation of the theoretical assumptions of the limitation clauses in the treaty provisions protecting the freedom to manifest religious beliefs, which are important from the European perspective, the author discusses the relevant provisions of the Convention, the Covenant and the Charter and analyzes the conditions of legal admissibility of limiting the right to manifest religious beliefs under the international instruments under discussion.

Key words: limiting rights and freedoms; system of human rights protection; freedom of conscience and religion; religious beliefs; Charter of Fundamental Rights of the European Union; Convention for the Protection of Human Rights and Fundamental Freedoms 


\section{WPROWADZENIE}

Artykuł 18 Powszechnej Deklaracji Praw Człowieka stanowi, że prawo do wolności myśli, sumienia i wyznania obejmuje wolność zmiany religii lub przekonań oraz wolność głoszenia swej religii lub przekonań, bądź indywidualnie, bądź wespół z innymi ludźmi, publicznie lub prywatnie poprzez nauczanie, praktykowanie, uprawianie kultu i praktyk religijnych ${ }^{1}$. W budowanym po II wojnie światowej międzynarodowym systemie ochrony praw człowieka, zadaniem PDPCz było proklamowanie praw człowieka jako standardu międzynarodowego, a tym samym wskazanie podstawowych treści samego pojęcia praw człowieka użytego w Karcie Narodów Zjednoczonych ${ }^{2}$.

Wolność uzewnętrzniania religii lub przekonań została określona analogicznie do art. 18 PDPCz w traktatowych aktach normatywnych, mających znaczenie dla europejskiego rozumienia standardu ochrony, w zakresie prawa do uzewnętrzniania religii lub przekonań na poziomie ponadpaństwowym i regionalnym. Wśród dokumentów mających takie znaczenie wymienić należy: na poziomie uniwersalnym - Międzynarodowy Pakt Praw Obywatelskich i Politycznych ${ }^{3}$ - podpisany i ratyfikowany przez wszystkie państwa europejskie; na poziomie regionalnym - Konwencję o Ochronie Praw Człowieka i Podstawowych Wolności ${ }^{4}$ - budującą efektywny system ochrony praw człowieka na forum Rady Europy

1 The Universal Declaration of Human Rights (Paris, 10.12.1948), https://www. un.org/en/ universal-declaration-human-rights/ [dostęp: 08.03.2021], dalej: PDPCz (tłum. własne). Użyty w art. 18 oraz traktatowych dokumentach, analizowanych w dalszej części rozważań, termin religion, tłumaczony jest w niniejszej pracy jako „religia”, a nie ,wyznanie", jak przyjmuje się w większości polskich oficjalnych tłumaczeń (poza tłumaczeniem Karty Praw Podstawowych UE).

2 Por. Kędzia 2018, 14-15.

3 Międzynarodowy Pakt Praw Obywatelskich i Politycznych otwarty do podpisu w Nowym Jorku dnia 16 grudnia 1966 r., Dz. U. z 1977 r. Nr 38, poz. 167, dalej: MPPOiP, art. 18 ust. 1.

4 Konwencja o Ochronie Praw Człowieka i Podstawowych Wolności sporządzona w Rzymie dnia 4 listopada 1950 r., zmieniona następnie Protokołami nr 3, 5 i 8 oraz uzupełniona Protokołem nr 2, Dz. U. z 1993 r. Nr 61, poz. 284 (wersja z wszystkimi protokołami dodatkowymi: https://www.echr.coe.int/Documents/Convention_POL.pdf [dostęp: 29.05.2021]), dalej: EKPC, art. 9 ust. 1. 
tworzonej przez 47 państw europejskich; oraz na poziomie ponadpaństwowym - Kartę Praw Podstawowych Unii Europejskiej ${ }^{5}$ - dokument wiążący prawnie państwa członkowskie Unii Europejskiej (ze świadomością przyjętych klauzul opt-out - np. protokół brytyjski), od momentu wejścia w życie Traktatu z Lizbony ${ }^{6}$. Art. 18 ust. 1 MPPOiP uznaje ,prawo do wolności myśli, sumienia i religii”, które w MPPOiP obejmuje „wolność posiadania lub przyjmowania religii lub przekonań według własnego wyboru oraz do uzewnętrzniania indywidualnie czy wspólnie z innymi, publicznie lub prywatnie, swej religii lub przekonań”. W art. 9 ust. 1 EKPC również uznawane jest prawo do wolności myśli, sumienia i religii, ale jego zakres wyznaczany jest nieco inaczej, bo „obejmuje [ono] wolność zmiany religii lub przekonań oraz wolność uzewnętrzniania indywidualnie lub wspólnie z innymi, publicznie lub prywatnie, swej religii lub przekonań". Ze względu na fakt, że w niniejszym artykule analizie poddany zostaje mechanizm limitacji uzewnętrzniania tylko przekonań o charakterze konfesyjnym, na potrzeby dalszych rozważań wydaje się uprawnione (przy świadomym pominięciu opisu finezyjnych doktrynalnych rozważań dotyczących rozumienia terminu „religia”, „wyznanie”, ,przekonania” w dokumentach praw człowieka) ${ }^{7}$, używanie roboczo - funkcjonującego w literaturze określenia ,„przekonania religijne”.

Wśród sposobów, według których dokonuje się uzewnętrznianie przekonań religijnych, wszystkie trzy cytowane artykuły wymieniają jednomyślnie: observance (,uprawianie kultu”), teaching („nauczanie”), practice (,praktykowanie”), worschip (w tłumaczeniu polskim EKPC: „czynności rytualne"; w thumaczeniu polskim KPP i w MPPOiP: ,uczestnictwo w obrzędach"). Za piąty sposób uzewnętrzniania przekonań religijnych można by uznać również - jak się wydaje - wyrażanie opinii o charakterze religijnym, rozpoznane w art. 19 MPPOiP i art. 10 EKPC. Wolność ta rzeczywiście jest ściśle związana z prawem do uzewnętrzniania przekonań

5 Charter of Fundamental Rights of the European Union (2012/C 326/02), Official Journal of the European Union, C 326, 26 October, dalej: KPP.

6 Treaty of Lisbon amending the treaty on European Union and the treaty establishing the European community signed at Lisbon 13 December 2007 (2007/C 3006/01), Official Journal of the European Union C 306 of 17 December 2012, art. 6, 1; por. Kubala 2015, 205-206; Księżniakiewicz 2012, 333-347.

Por. Sobczak, Gołda-Sobczak 2012, 28-23. 
religijnych i jakkolwiek na gruncie EKPC przyjęto doktrynalnie uznawać swobodę wypowiedzi jako prawo autonomiczne, posiadające walor ogólny w stosunku do wypowiedzi wkraczających w dziedziny objęte treścią innych praw, co uzasadniałoby szukanie ochrony dla wypowiedzi o charakterze konfesyjnym bardziej w art. 9 niż 10 EKPC, to jednak Europejski Trybunał Praw Człowieka w Strasburgu (ETPC) wypowiedzi związane $\mathrm{z}$ uzewnętrznianiem przekonań religijnych wiąże w swoim orzecznictwie $\mathrm{z}$ art. $10 \mathrm{EKPC}^{8}$.

Prawo do uzewnętrzniania przekonań religijnych, podobnie jak inne prawa człowieka, może podlegać ograniczeniom nakładanym na poszczególne prawa w różny sposób i w różnym zakresie. Przyjmuje się trzy sposoby ograniczania praw człowieka, w formie tak zwanych wyjątków ex definitione (postanowień wskazujących, że określone działanie nie jest traktowane jako naruszenie danego prawa), klauzul derogacyjnych (określających na jakich warunkach dopuszczalne jest zawieszenie określonych praw i wolności) czy klauzul limitacyjnych (określających zasady dopuszczalności ingerencji władz w sferę praw człowieka) ${ }^{9}$. Ten ostatni mechanizm jest obecny w przytoczonych wyżej przepisach statuujących wolność uzewnętrzniania religii i przekonań. W literaturze znaleźć można wiele opracowań teoretycznych na temat klauzul limitacyjnych oraz opracowań stanów faktycznych, ilustrujących ograniczenia konkretnych aspektów wolności uzewnętrzniania religii i przekonań. Do tych znanych doktrynie ustaleń odwołuje się Autor niniejszego artykułu celem realizacji wyznaczonego zadania badawczego.

Przedmiotem niniejszego opracowania jest mechanizm limitacji w traktatowych aktach normatywnych, mających znaczenie dla europejskiego rozumienia standardu ochrony $\mathrm{w}$ zakresie prawa do uzewnętrzniania religii lub przekonań na poziomie ponadpaństwowym i regionalnym. W pracy realizowanej metodą dogmatyczno-prawną podjęta zostaje próba odpowiedzi na pytanie badawcze: jakie są praktycznoprawne konsekwencje realizacji założeń teoretycznych klauzuli limitacyjnej w - istotnych z europejskiego punktu widzenia - przepisach traktatowych statuujących wolność uzewnętrzniania przekonań religijnych?

8 Warchałowski 2002, 210.

9 Radajewski 2015, 129; por. Jasudowicz 1997, 48-50; Latos 2008. 
Celem odpowiedzi, analizie zostaną poddane odnośne przepisy EKPC i MPPOiP. Omówione zostaną również warunki prawnej dopuszczalności limitacji prawa do uzewnętrzniania przekonań religijnych na gruncie przepisów EKPC i MPPOiP, a następnie mechanizm limitacji prawa do uzewnętrzniania przekonań religijnych zostanie poddany analizie na gruncie KPP. Część końcową pracy stanowić będą wnioski, budujące odpowiedź na postawione pytanie badawcze.

\section{TEORETYCZNE ZAŁOŻENIA KLAUZULI LIMITACYJNEJ A PRZEPISY LIMITUJĄCE WOLNOŚĆ UZEWNĘTRZNIANIA PRZEKONAŃ RELIGIJNYCH W EKPC I W MPPOIP}

Podczas gdy twórcy PDPCz przyjęli w całym dokumencie jedną ogólną klauzulę limitacyjną dla całego katalogu praw, w EKPC i w MPPOiP stosowane są klauzule szczegółowe, powiązane z konkretnymi przepisami dotyczącymi poszczególnych praw i różniące się między sobą w zależności od praw, których dotyczą ${ }^{10}$. Jakkolwiek obecne w EKPC klauzule limitacyjne nazywane są klauzulami ograniczającymi, bo stanowią konstrukcję umożliwiającą ograniczanie praw i wolności jednostek, to - jak zauważają badający EKPC prawnicy - sama konstrukcja klauzuli limitacyjnej obejmuje kilka formuł, przewidujących różny zakres ograniczeń, a limitacja może czasami prowadzić do rozszerzenia zakresu prawa gwarantowanego w EKPC ${ }^{11}$.

Klauzula limitacyjna dotycząca prawa do uzewnętrzniania przekonań religijnych została zawarta w art. 9 ust. 2 EKPC oraz w art. 18 ust. 3 MPPOiP. Porównywanie obu przepisów jest uprawnione, ponieważ art. 9 stanowił oczywisty punkt odniesienia dla ostatecznej redakcji

10 Piechowiak 2009, 62. Biorąc pod uwagę kontekst polskiego czytelnika, należy zauważyć, że Konstytucja RP zawiera w art. 31 ust. 3 klauzulę o charakterze ogólnym, ale dopełnianą przez klauzule szczególne, co ma istotne znaczenie zwłaszcza w przypadku ograniczania wolności uzewnętrzniania religii (Konstytucja Rzeczypospolitej Polskiej z dnia 2 kwietnia 1997 r., Dz. U. z 1997 r. Nr 78, poz. 483 z późn. zm., art. 53 ust. 5). W tym kontekście - jak zauważają niektórzy autorzy - art. 31 ust. 3 Konstytucji RP wykazuje szereg analogii z klauzulami ograniczającymi, zastosowanymi właśnie w MPPOiP oraz w EKPC. Por. Zakolska 2005, 11-29; Wojtyczek 1999, 78-80.

11 Liżewski 2016, 196-197; por. Latos 2008, 151. 
art. 18 MPPOiP $^{12}$. W obu przypadkach pierwszy człon przepisu jest taki sam i stanowi: ,wolność uzewnętrzniania religii lub przekonań może podlegać jedynie takim ograniczeniom, które są przewidziane przez ustawę i są konieczne”, przy czym EKPC dodaje w art. 9 ust. 2: „w społeczeństwie demokratycznym". W następnej części oba przepisy zawierają praktycznie taki sam katalog celów prawowitych, czyli katalog wartości, dla obrony których za uzasadnioną należałoby uznać dopuszczalność ingerencji władzy publicznej w korzystanie $\mathrm{z}$ danego prawa. Cele prawowite w obu przepisach to ochrona bezpieczeństwa publicznego, porządku publicznego, zdrowia, moralności, praw i wolności innych osób. Jak zauważa T. Jasudowicz, w odniesieniu do art. 9 ust. 2 EKPC, spośród pięciu limitowalnych praw (art. 8-11 EKPC oraz art. 2 Protokołu IV do EKPC) „najuboższy, bo pięcioskładnikowy katalog celów prawowitych towarzyszy wolności manifestowania religii i przekonań" ${ }^{13}$. Rzeczywiście w art. 9 EKPC - inaczej niż w pozostałych czterech przypadkach - brakuje celu prawowitego: bezpieczeństwa narodowego. Podobna sytuacja ma miejsce w MPPOiP, którego art. 18 ust. 3 również nie wymienia bezpieczeństwa narodowego wśród wartości uzasadniających limitację prawa do uzewnętrzniania przekonań religijnych.

Ze względu na - wykazane we wstępie - orzecznicze powiązanie prawa do uzewnętrzniania przekonań religijnych z art. 10 EKPC, a przez to z analogicznym art. 19 MPPOiP, za klauzule limitacyjne prawa do uzewnętrzniania przekonań o charakterze religijnym uznać można pośrednio również przepisy art. 19 ust. 3 MPPOiP oraz art. 10 ust. 2 EKPC, choć przedmiot limitacji jest tam szerszy, bo dotyczy prawa do wyrażania wszelkich opinii ${ }^{14}$.

Opisywane klauzule odnoszą się tylko do limitowalnego forum externum religijnych wolności jednostki, podczas gdy odnośne wolności forum internum nie mogą być w żaden sposób ograniczane ${ }^{15}$. Katalog celów prawowitych w art. 19 ust. 3 MPPOiP jest dość schematyczny (poszanowanie praw i dobrego imienia innych; ochrona bezpieczeństwa narodowego, porządku publicznego lub moralności publicznej) i w zakresie

12 Garlicki 2010, 551-553.

13 Jasudowicz 2012, 112.

14 Piechowiak 2009, 63.

15 Murdoch 2012, 18-22. 
uzasadnienia limitacji prawa uzewnętrzniania przekonań religijnych zasadniczo (oprócz przesłanki bezpieczeństwa narodowego) wpisuje się w katalog celów prawowitych art. 9 EKPC oraz art. 18 MPPOiP. Podobnie, art. 10 ust. 2 EKPC, jakkolwiek zawiera bardziej rozbudowany katalog celów prawowitych $(,[\ldots] \mathrm{w}$ interesie bezpieczeństwa państwowego, integralności terytorialnej lub bezpieczeństwa publicznego ze względu na konieczność zapobieżenia zakłóceniu porządku lub przestępstwu, z uwagi na ochronę zdrowia i moralności, ochronę dobrego imienia i praw innych osób oraz ze względu na zapobieżenie ujawnieniu informacji poufnych lub na zagwarantowanie powagi i bezstronności władzy sądowej”), to $\mathrm{w}$ zakresie limitacji prawa do uzewnętrzniania przekonań religijnych, również - jak łatwo wywnioskować z przytoczonego w nawiasie tekstu można uznać, że wpisuje się zasadniczo w cele prawowite wymieniane w art. 9 ust. 2 EKPC oraz art. 18 ust. 3 MPPOiP.

Budowa klauzuli limitacyjnej wprowadzona do treści art. 9 ust. 2 EKPC wpisuje się w ogólny schemat budowy tzw. pełnych klauzul ograniczających, które cechuje: (a) opisywanie warunków dopuszczalnej ingerencji za pomocą pojęć otwartych, które nie nawiązują bezpośrednio do treści uprawnienia, (b) możliwość stosowania tak w stanach nadzwyczajnych, jak i w okresie normalnego funkcjonowania państwa, (c) ograniczenie uprawnień w celu realizacji interesu indywidualnego lub publicznego, (d) specyficzna budowa ${ }^{16}$. W te ogólne założenia wydaje się również wpisywać klauzula limitacyjna zawarta w treści art. 18 ust. 3 MPPOiP.

Odnośnie do kryterium specyficznej budowy - klauzula limitacyjna w EKPC opiera się na powiązaniu trzech elementów, jakimi są: (a) adresat upoważniony do ograniczenia prawa, (b) szacunkowe wskazanie na konieczność dokonania takiej ingerencji, (c) powody, ze względu na które ingerencja taka jest dokonywana ${ }^{17}$. Biorąc pod uwagę wszystkie pięć pełnych klauzul limitacyjnych, zawartych w ustępach drugich art. 8, 9, 10, 11 i art. 2 Protokołu IV EKPC, dają się zauważyć pewne gramatyczne czy treściowe różnice. Przykładem takich różnic są analizowane przepisy art. 9 ust. 2 czy art. 10 ust. 2 EKPC, które różni od pozostałych klauzul limitacyjnych użycie pozytywnej formuły limitacji.

16 Mizerski 2013, 92.

17 Liżewski 2016, 198. 
Nie jest to jednak różnica na tyle istotna, by uniemożliwiała stosowanie jednakowej metodologii wykładni wszystkich pełnych klauzul limitacyjnych $\mathrm{EKPC}^{18}$.

Odnośnie do pierwszego elementu konstrukcyjnego klauzuli limitacyjnej EKPC, adresatem pierwotnym upoważnienia do ograniczenia prawa jest ustawodawca - a idąc za dosłownym thumaczeniem tekstu oryginalnego prawodawca. Dokładne określenie adresata ma znaczenie, jak podkreślają autorzy, w kontekście państw członkowskich Rady Europy z kręgu tradycji prawnej common law, ze względu na inne od ustawowych możliwości stanowienia prawa ${ }^{19}$. Za adresatów wtórnych możliwości dokonywania ograniczeń uznać należy stosujące prawo organy, które wydają konkretne akty, w oparciu o normy abstrakcyjne i generalne, czego efektem są czynności faktyczne organów państwowych, takie jak np. stosowanie środków przymusu bezpośredniego ${ }^{20}$. Wydaje się, że takie rozumienie pierwszego elementu konstrukcyjnego klauzuli limitacyjnej w art. 9 ust. 2 EKPC można przyjąć również odnośnie do art. 18 ust. 3 MPPOiP, gdzie pojawia się również pojęcie ograniczeń przewidzianych przez ustawę (czy precyzyjniej: przez prawo).

Drugi element klauzul limitacyjnych w EKPC - nazywany niekiedy klauzulą konieczności - to szacunkowe wskazanie na konieczność dokonania takiej ingerencji ${ }^{21}$. „Nie chodzi tu o jakąkolwiek bliżej nieokreśloną konieczność, lecz o konieczność występującą w społeczeństwie demokratycznym"22. Sytuacyjny i szacunkowy wymiar konieczności jest tutaj w pewien sposób obiektywizowany ,przez zestawienie jej ze stabilnymi i ugruntowanymi już wartościami demokratycznego społeczeństwa, [co] wzmacnia aksjologiczny wymiar dokonania ograniczeń praw człowieka"23. Tego typu aksjologicznego wzmocnienia owej konieczności, uzasadniającej ograniczenie praw, nie znajdujemy w art. 18 ust. 3 MPPOiP, bo - jak wskazano już wyżej - brakuje tam sformułowania ,w społeczeństwie demokratycznym", jakkolwiek dla porządku należy wskazać, że

\footnotetext{
18 Tamże.

19 Kamiński 2020, 3.

20 Liżewski 2016, 198-199.

21 Tamże, 199.

22 Tamże.

23 Tamże.
} 
sama klauzula konieczności w społeczeństwie demokratycznym użyta zostaje w klauzuli limitacyjnej art. 21 i 22 MPPOiP, a samo sformułowanie „W społeczeństwie demokratycznym” - w przepisie art. 14 MPPOiP. Uzasadniać tę różnicę wydaje się fakt, że MPPOiP został przyjęty przecież również przez państwa niedemokratyczne, a państwa-strony EKPC są - przynajmniej w ustrojowych założeniach - demokratyczne. Samo kryterium konieczności jest jednak obecne w klauzuli limitacyjnej art. 18 ust. 3 MPPOiP, z tym że jego aksjologicznym wzmocnieniem nie są tu wartości państwa demokratycznego determinujące rozumienie celów prawowitych, a same cele prawowite jako ostateczna motywacja dokonywanych limitacji. Rozumienie celów prawowitych wymienianych w MPPOiP wyznaczają: dokument przyjęty 28 września 1984 r. w ramach prac Rady Gospodarczej i Społecznej - nazywany Zasady z Syrakuz ${ }^{24}$ oraz oficjalny Komentarz Komitetu Praw Człowieka Organizacji Narodów Zjednoczonych (KPCz ONZ) do art. $18 \mathrm{MPPOiP}^{25}$. Ową konieczność definiują na gruncie MPPOiP bezpośrednio i precyzyjnie opisane cele prawowite, natomiast na gruncie EKPC kryterium wartości demokratycznych, często dyskrecjonalnie definiowane, a przez to skutkujące społeczną polaryzacją tego typu odniesień. Uprawniona wydaje się zatem opinia, że rozumienie przesłanki „konieczności” zawartej w klauzuli limitacyjnej art. 18 ust. 3 MPPOiP jest bardziej precyzyjne od rozumienia tej przesłanki w brzmieniu art. 9 ust. 2 EKPC.

Ten sposób rozumowania wydaje się być zresztą potwierdzony przez samych twórców EKPC, którzy tworzyli trzeci element klauzul limitacyjnych (klauzule generalne, statuujące wartości - cele prawowite - uzasadniające wprowadzenie ograniczeń) właśnie po to, by uniemożliwić zbyt uznaniowe limitowanie praw człowieka, a przez to dezintegrowanie systemu ochrony - dokonywane przez ustawodawcę państwowego - tylko

24 Economic and Social Council UN (Commission on Human Rights 41 session), Status of the International covenants on human rights, annex: The Siracusa principles on the Limitation and Derogation Provisions in the International Covenant on Civil and Political Rights, E.CN.4/1985/4, dalej: Zasady.

25 Por. UN Human Rights Committee (HRC), CCPR General Comment No. 22: Article 18 (Freedom of Thought, Conscience or Religion), 30 July 1993, CCPR/C/21/Rev.1/Add.4, https://www.refworld.org/docid/453883fb22.html [dostęp: 30.05.2021], dalej: Komentarz; por. Wieruszewski 2012, 419-460. 
w oparciu o tak zwane ,zobiektywizowane wartości społeczeństwa demokratycznego" 26 .

W art. 18 ust. 3 MPPOiP same cele stanowią o konieczności wprowadzenia ograniczeń.

\section{KLAUZULE LIMITACYJNE W EKPC I MPPOIP A WARUNKI PRAWNEJ DOPUSZCZALNOŚCI OGRANICZEŃ W PORZĄDKU PAŃSTWOWYM}

W opisanych wyżej trzech elementach konstrukcyjnych klauzul limitacyjnych EKPC określone zostają trzy przesłanki, nazywane również testami, które muszą zostać łącznie spełnione, aby ETPC badający ich występowanie w określonym przypadku mógł stwierdzić, czy dana ingerencja władzy publicznej nie stanowiła naruszenia odnośnego prawa czy wolności ${ }^{27}$. Wymienić należy tu odpowiednio przesłanki: (a) legalności formalnej-czyli ustanowienia przez prawo - nazywanej testem legalności, (b) legalności materialnej - czyli powiązania z jednym z celów prawowitych - nazywanej testem celowości, (c) niezbędności - czyli konieczności w demokratycznym społeczeństwie - nazywanej testem konieczności ${ }^{28}$.

Konieczność dokładnego zbadania dopuszczalności ograniczeń ma znaczenie również ze względu na art. 18 EKPC, który stanowi, że „ograniczenia praw i wolności, na które zezwala niniejsza konwencja nie będą stosowane w innych celach niż te, dla których je wprowadzono"29. Jak zauważa R. Mizerski - ,istotą testu legalności jest zbadanie czy państwo-strona postępuje zgodnie z prawem, do którego odsyła - co najmniej w sposób dorozumiany - Konwencja”, co uprawnia kontrolę ze strony $\mathrm{ETPC}^{30}$. Przez wiele lat test legalności oparty tylko na przepisach EKPC (art. 5 ust. 1; art. 8 ust. 2; art. 12) sprowadzał się do stwierdzenia, czy $\mathrm{w}$ momencie wprowadzania ograniczeń istniała $\mathrm{w}$ krajowym porządku prawnym podstawa prawna będąca źródłem ograniczenia, przy czym ETPC

\footnotetext{
26 Liżewski 2016, 199-200.

27 Jasudowicz 2012, 110-111.

28 Garlicki 2010, 550-552; por. Szuniewicz 2016, 34-60.

29 Por. Skrzydło 2013, 3-9.

30 Mizerski 2013, 93.
} 
dopuszcza w systemach common law oparcie ingerencji również na normie niepisanej ${ }^{31}$. W 1979 r. ETPC sformułował w swoim orzecznictwie wymogi jakościowe dostępności i przewidywalności, jakie powinny charakteryzować prawo będące podstawą ingerencji w uprawnienie ${ }^{32}$. W 1983 r. ETPC uzupełnił te wymogi jakościowe wymogiem stworzenia przez państwo efektywnego środka kontroli prawa wprowadzającego ograniczenia, co nakładało na prawodawcę obowiązek tworzenia w porządku krajowym odnośnych instytucjonalnych i proceduralnych zabezpieczen ${ }^{33}$.

Za przykład pomyślnie przeprowadzonego testu legalności w odniesieniu do klauzuli limitacyjnej zawartej w art. 9 ust. 2 EKPC często podawane jest orzeczenie Kokkinakis przeciwko Grecji, gdzie wnioskodawca podniósł, że ograniczenie nie było ,,przewidziane przez prawo”, bo prozelityzm, o który był oskarżany nie został precyzyjnie zdefiniowany, a w tekście ustawy posłużono się zwrotami „w szczególności” oraz „pośrednie usiłowanie”, co zdaniem wnioskodawcy miało służyć możliwości uznania przez organy państwowe, że każda rozmowa na temat religii czy konwersja mogłyby zostać uznane za działania objęte dyspozycją § 4 greckiej ustawy 1363/1938. Według władz przepis był precyzyjny, ponieważ podstawowy element przestępstwa prozelityzmu to dopuszczenie się próby zmiany przekonań religijnych innej osoby, a zwrot „w szczególności” odnosi się jedynie do sposobu działania. ETPC oceniając stanowiska stron stwierdził, że przepisy o prozelityzmie należą do kategorii pojęć niedookreślonych, używanych w aktach prawnych dla uniknięcia zbytniej sztywności. Doprecyzowanie tych pojęć następuje dzięki orzecznictwu, a sądy greckie wydały wiele orzeczeń dotyczących $§ 4$ ustawy 1363/1938. Kokkinakis mógł w wystarczający sposób przewidzieć konsekwencje swojego postępowania $^{34}$. Przykładem negatywnego wyniku testu legalności w spra-

31 Tamże, 94; por. Mizerski 2009.

32 Wyrok ETPC z dnia 26 kwietnia 1979 r., Sunday Times przeciwko Zjednoczonemu Królestwu (1), skarga nr 6538/74, A 30, za: Murdoch 2012, 39.

33 Wyrok ETPC z dnia 25 marca 1983 r., Silver i inni przeciwko Zjednoczonemu Królestwu, skargi nr 5947/72, 6205/73, 7052/75, 7107/75, 7136/75, A 61, pkt 90, za: Mizerski 2013, 94.

34 Wyrok ETPC z dnia 25 maja 1993 r., Kokkinakis v. Greece, skarga nr 14307/88, § 37-44, http://www.bailii.org/eu/cases/ECHR/1993/20.html [dostęp: 31.05.2021], dalej: Kokkinakis; por. http://www.policy.hu/kaminski/Kokkinakis.htm [dostęp: 31.05.2021]. 
wach rozpatrywanych w oparciu o art. 9 ust. 2 może być orzeczenie w sprawie Hasan i Chaush przeciwko Bułgarii, gdzie EKPC - rozpatrując kwestie faworyzowania przez organ państwowy jednej frakcji wobec drugiej, w sporze dotyczącym wyznaczenia przywódcy religijnego - stwierdził, że braki kryteriów materialnych w odnośnych przepisach, jak również brak gwarancji procesowych, czyniły ingerencję władz arbitralną ${ }^{35}$.

Odnośnie do testu celowości T. Jasudowicz zauważa, że „,W sformułowaniu tekstu klauzul limitacyjnych, test celowości jakby nie występował samodzielnie, skoro katalog celów prawowitych poprzedzony jest zwrotem określającym ingerencję władzy publicznej jako konieczną w demokratycznym społeczeństwie dla enumeratywnie wymienianych następnie celów prawowitych" 36 . Jeśli patrzymy na opisane wyżej trzy elementy konstrukcyjne klauzuli limitacyjnej, to rzeczywiście klauzula konieczności (test konieczności) poprzedza katalog celów prawowitych (test celowości). Ta kolejność jest jednak - jak zauważa T. Jasudowicz - „tylko pozorna”37. W praktyce ETPC ,jeśli w ogóle - najpierw odnotowuje czy - co rzadziejkonkretny cel czy też cele prawowite bada i interpretuje. Nieraz następuje to dopiero przy okazji badania testu konieczności, a to w ramach kryterium proporcjonalności zastosowanych środków do konieczności realizacji celu czy celów prawowitych" 38 . W odniesieniu do testu celowości w ograniczeniach dotyczących uzewnętrzniania przekonań religijnych autorzy wskazują, że zazwyczaj kryterium to nie stwarza problemu dla pozwanych państw, którym łatwo wykazać celowość ograniczenia, a ETPC, przeprowadzający test celowości, dość łatwo uzna wskazany przez państwo cel za mieszczący się w katalogu celów prawowitych. W cytowanej sprawie Kokkinakis przeciwko Grecji, EKPC przyjął linię argumentacyjną władz, że zakaz prozelityzmu miał na celu ochronę praw i wolności innych ${ }^{39}$.

Test konieczności bywa nazywany „najbardziej wartościującym etapem rozstrzygania o dopuszczalności ingerencji”40. ETPC bada, czy

35 Hasan i Chaush przeciwko Butgarii (Wielka Izba), § 84-85, za: Murdoch 2012, 39-40.

36 Jasudowicz 2012, 111.

37 Tamże.

38 Tamże.

39 Kokkinakis, § 44.

40 Mizerski 2013, 95. 
zgodna z prawem i realizująca cel prawowity ingerencja była konieczna, innymi słowy, czy przyczyny ograniczenia uprawnienia znajdują uzasadnienie w wartościach i prawidłowym funkcjonowaniu społeczeństwa demokratycznego, a przynajmniej nie kolidują z nimi, to znaczy mieszczą się w zakresie implementacyjnej swobody pozostawianej stronom EKPC (nazywanej marginesem oceny) ${ }^{41}$. Z tego powodu nie będzie proste również łatwe przeprowadzenie testu konieczności w odniesieniu do przepisów krajowych ograniczających wolność uzewnętrzniania religii. „Skarżone naruszenie musi: (a) odpowiadać naglącej potrzebie społecznej, (b) być proporcjonalne do zamierzonego, prawnie uzasadnionego celu, (c) być uzasadnione istotnymi i wystarczającymi przyczynami"42. Cechująca test konieczności pewna labilność aksjologiczna została w pewien sposób przezwyciężona dzięki orzeczniczemu wskazaniu przez EKPC cech europejskiego społeczeństwa demokratycznego, takich jak np. otwartość umysłu, tolerancja czy pluralizm ${ }^{43}$. W kontekście tych wartości pozytywnie przeprowadzony został test konieczności w sprawie Otto-Preminger-Institut, gdzie uznano za słuszne ograniczenia mające na celu ochronę wierzących przed obelżywymi atakami słownymi ${ }^{44}$.

Gdy szukamy na gruncie MPPOiP kryteriów pozwalających ocenić dopuszczalność ograniczenia przez państwo wolności uzewnętrzniania przekonań religijnych - a taką dopuszczalność badać przecież może $\mathrm{KPCz}$ ONZ na podstawie postanowień 1. Protokołu fakultatywnego do MPPOiP (wprowadzającego instytucję skargi prywatnej obywatela przeciwko państwu), podstawowym narzędziem jest katalog celów podstawowych $\mathrm{z}$ art. 18 ust. 3 oraz jego szczegółowa interpretacja wśród Zasad - określających reguły interpretacyjne przepisów limitacyjnych w MPPOiP ${ }^{45}$. Warto zauważyć, że owe reguły interpretacyjne omawiają nie tylko same cele prawowite zawarte $\mathrm{W}$ MPPOiP, ale również inne elementy klauzuli

41 Tamże; por. Rozner 2002, 126-127.

42 Murdoch 2012, 41.

43 Kokkinakis, $\S 31$.

44 Murdoch 2012, 43, 73-74; por. wyrok ETPC z dnia 20 września 1994 r., Otto-Preminger-Institut, skarga nr 13470/87, https://sip.lex.pl/orzeczenia-i-pisma-urzedowe/ orzeczenia-sadow/13470-87-otto-preminger-institut-v-austria-wyrok-520174218 [dostęp: 12.11.2021].

45 Zasady, art. 15-39. 
limitacyjnej - jak np. będąca odpowiednikiem testu legalności z EKPC przesłanka, by ograniczenie prawa człowieka wprowadzane przez państwo wypełniało nakaz ustawowy ${ }^{46}$. Prawo ograniczające wykonywanie praw człowieka nie może być arbitralne ani nieracjonalne, natomiast zasady prawne limitujące wykonywanie praw człowieka muszą być jasne i dostępne dla każdego ${ }^{47}$.

Cel prawowity bezpieczeństwa publicznego oznacza w Zasadach ochronę osób ze względu na niebezpieczeństwo, zagrażające ich życiu lub integralności fizycznej, albo mieniu. Można powoływać się na ten cel w ograniczeniach, gdy istnieją odpowiednie zabezpieczenia i skuteczne środki zaradcze przeciwko nadużyciom ${ }^{48}$.

Cel prawowity porządku publicznego definiowany w Zasadach oznacza sumę reguł społeczeństwa lub zbiór podstawowych zasad, na których opiera się społeczeństwo. Poszanowanie praw człowieka jest częścią porządku publicznego, a samo pojęcie porządku publicznego - w tekście Zasad użyte zostaje również francuskie określenie ordre public - należy interpretować w kontekście celu określonego prawa człowieka, które jest na tej podstawie ograniczone. Organy państwowe lub osoby odpowiedzialne za utrzymanie porządku publicznego podlegają kontroli w wykonywaniu swoich uprawnień za pośrednictwem parlamentu, sądów lub innych kompetentnych niezależnych organów ${ }^{49}$. Należy zauważyć, że ten cel prawowity użyty w EKPC i MPPOiP w klauzuli manifestowania religii i przekonań, został użyty jeszcze tylko raz w obu dokumentach - w EKPC, $\mathrm{w}$ przepisie dotyczącym przemieszczania się, a w MPPOiP w przepisie gwarantującym prawo do sądu ${ }^{50}$.

Cel prawowity zdrowia publicznego definiowany jest jako podstawa do ograniczenia niektórych praw w celu umożliwienia państwu podjęcia działań w przypadku poważnego zagrożenia zdrowia ludności lub poszczególnych jej członków. Środki te muszą być szczególnie ukierunkowane na zapobieganie chorobom lub urazom oraz na zapewnienie opieki chorym

\footnotetext{
46 Zasady, art. 15-18.

47 Tamże.

48 Zasady, art. 33-34.

49 Tamże, art. 22-24.

50 Art. 2 EKPC; art. 14 MPPOiP.
} 
i rannym. Należy zwrócić uwagę na międzynarodowe przepisy zdrowotne Światowej Organizacji Zdrowia ${ }^{51}$.

Cel prawowity moralności publicznej opisywany jest w Zasadach jako podstawa do ograniczenia praw człowieka, przy zachowaniu pewnego marginesu swobody, biorącego pod uwagę zmiany społeczne i kulturowe redefiniujące pojęcie moralności. Powołujący się na ten cel prawowity powinni wykazać, że dane ograniczenie ma zasadnicze znaczenie dla zachowania szacunku dla podstawowych wartości wspólnoty. Margines swobody pozostawiony państwom nie ma zastosowania do zasady niedyskryminacji określonej w MPPOiP ${ }^{52}$.

Artykuły Zasad definiujące ochronę praw i wolności innych osób jako cel prawowity zawierają zastrzeżenie, że zakres praw i wolności innych osób, mogących stanowić ograniczenie praw zawartych w MPPOiP, wykracza poza prawa i wolności uznane w MPPOiP. W przypadku konfliktu między prawem chronionym w MPPOiP a prawem niepodlegającym takiej ochronie, pod rozwagę należy wziąć fakt, że MPPOiP chroni najbardziej fundamentalne prawa i wolności. W tym kontekście największą wagę należy przywiązywać do praw, których niederogowalność może zostać wywiedziona $\mathrm{z}$ art. 4 MPPOiP $\mathrm{M}^{53}$.

Interpretację powyższych celów prawowitych, w kontekście art. 18 MPPOiP, umożliwia również wspomniany wyżej Komentarz, który charakteryzuje ograniczenia z ust. 3 art. 18 przypominając, że stosowane ograniczenia motywowane opisanymi wyżej celami prawowitymi mogą dotyczyć jedynie forum externum. Interpretując cel dopuszczalnego ograniczenia klauzuli, państwa-strony powinny kierować się ochroną praw gwarantowanych w MPPOiP, w tym prawa do równości i niedyskryminacji na wszystkich podstawach określonych w art. 2, 3 i 26. KPCz ONZ zauważa również, że art. 18 ust. 3 MPPOiP należy interpretować ściśle, co znaczy, iż ograniczenia nie są dozwolone z powodów tam niewyszczególnionych. Ograniczenia mogą być stosowane wyłącznie do celów, dla których zostały przewidziane i muszą być bezpośrednio związane i proporcjonalne do konkretnej potrzeby, na której są oparte. Ograniczenia nie mogą być nakładane

\footnotetext{
51 Zasady, art. 25-26.

52 Zasady, art. 27-28; por. Mojski 2014, 598.

53 Zasady, art. 35-37.
} 
w celach dyskryminacyjnych ani stosowane w sposób dyskryminujący ${ }^{54}$. KPCz ONZ zauważył również, że pojęcie moralności wywodzi się z wielu tradycji społecznych, filozoficznych i religijnych. W konsekwencji, ograniczenia wolności uzewnętrzniania religii lub przekonań w celu ochrony moralności muszą opierać się na zasadach niewywodzących się wyłącznie z jednej tradycji. Osoby już podlegające pewnym uzasadnionym ograniczeniom, takie jak więźniowie, nadal korzystają ze swoich praw do uzewnętrzniania własnych przekonań religijnych lub przekonań w najpełniejszym zakresie, zgodnym ze szczególnym charakterem ograniczenia. Raporty państw-stron powinny zawierać informacje o pełnym zakresie i skutkach ograniczeń wynikających z art. 18 ust. 3 MPPOiP ${ }^{55}$.

Jednakowy formalnie katalog celów prawowitych i podobna ich wykładnia w obu systemach ochrony nie pozwalają jednak mówić o tożsamych systemach limitacyjnych w zakresie prawa do uzewnętrzniania przekonań religijnych ze względu na inaczej rozumianą przesłankę konieczności czy konkretniej, inne w obu systemach jej aksjologiczne uzasadnienie (na gruncie EKPC - wartości państwa demokratycznego determinują rozumienie celów prawowitych; na gruncie MPPOiP same cele prawowite stanowią ostateczną motywację dokonywanych limitacji), warunkowane - jak pokazano już w poprzednim paragrafie - nieco innym kręgiem odbiorców EKPC i MPPOiP, a co za tym idzie koniecznością uwzględnienia różnych uwarunkowań kulturowych.

W kontekście limitacji prawa do uzewnętrzniania przekonań religijnych rozbieżność w rozstrzygnięciach $\mathrm{KPCz}$ ONZ i w orzecznictwie ETPC obrazuje orzecznicza ocena (dokonywana jeszcze przed wybuchem pandemii COVID-19) ustawodawstwa zabraniającego zasłaniania twarzy w miejscach publicznych. KPCz ONZ uznał takie ustawodawstwo za niezgodne $\mathrm{z}$ art. 18 MPPOiP, podczas gdy ETPC uznawał zasadność tego typu ograniczeń w oparciu o klauzulę limitacyjną art. $9 \mathrm{EKPC}^{56}$. Zaznaczyć należy, że w wyroku S.A.S. przeciwko Francji, wyznaczającej kierunek

54 Komentarz, n. 8.

55 Tamże.

56 Por. stanowisko KPCz ONZ z dnia 17 lipca 2018 r., skarga nr 2807/2016, Miriana Hebbadi przeciwko Francji; stanowisko KPCz ONZ z dnia 17 lipca 2018 r., skarga nr 2747/2016, Sonia Yaker przeciwko Francji; por. wyrok ETPC z dnia 1 lipca 2014 r., S.A.S. przeciwko Francji, skarga nr 43835/11; wyrok ETPC z dnia 11 lipca 2017 r., Dakir 
rozstrzygnięć w tego typu sprawach, ETPC uznając, że definiowanie warunków życia wspólnotowego leży w wyłącznej gestii poszczególnych państw (§ 141 wyroku), umieścił de facto wartość „,̇ycia wspólnotowego” (vivre ensemble), która w EKPC nie występuje, w katalogu „praw i wolności innych osób”, nie decydując się jednocześnie na zakwalifikowanie tej wartości jako zasady porządku publicznego albo wkomponowania jej w kontekst bezpieczeństwa państwa, przyznając, że nie znajduje podstaw dla tego typu działania ${ }^{57}$. Jakkolwiek takie postępowanie może skłaniać do wniosku, że ratio decidendi ETPC nie bazuje na klauzuli limitacyjnej $\mathrm{z}$ art. 9 EKPC, a jest przejawem aktywizmu sędziowskiego (taki wniosek można wysnuć ze sprawozdań np. Amnesty International) ${ }^{58}$, zauważyć należy, że tego typu reinterpretacja celu prawowitego, jakkolwiek nie do końca uprawniona w powszechnej opinii, wpływa de facto na kształt całego mechanizmu limitacyjnego.

\section{LIMITACJA UZEWNĘTRZNIANIA PRZEKONAŃ RELIGIJNYCH NA GRUNCIE KARTY PRAW PODSTAWOWYCH UE}

Odnośnie do ograniczenia wolności uzewnętrzniania przekonań religijnych w Karcie Praw Podstawowych UE zauważyć należy w pierwszej kolejności różnice między art. $10 \mathrm{KPP}$ a analizowanymi wyżej przepisami. Podobnie jak wyżej, prawo do wolność myśli, sumienia i religii obejmuje wolność zmiany i uzewnętrzniania przekonań religijnych ${ }^{59}$. Ze względu na umieszczenie w ust. 2 art. 10 KPP prawa do odmowy działania sprzecznego $\mathrm{z}$ własnym sumieniem, zakres tego prawa wydaje się być jednak

przeciwko Belgii, skarga nr 4619/12; wyrok ETPC z dnia 11 lipca 2017 r., Belcacemi i Oussar przeciwko Belgii, skarga nr 37798/13, za: Kamiński 2020, 37, 11.

57 Wyrok ETPC z dnia 1 lipca 2014 r., S.A.S. przeciwko Francji, skarga nr 43835/11, $\S 141$, w: Nowicki, Marek Antoni. 2014. Europejski Trybunat Człowieka. Wybór orzeczeń: LEX/el, 2015; por. Falski 2020, 55-60.

58 Por. Raport roczny Amnesty International 2014/15. Sytuacja praw człowieka na świecie, s. 46, 65 https://amnesty.org.pl/wp-content/uploads/2016/04/Raport_roczny_2014_15_PL_wybrane-1.pdf [dostęp: 16.08.2021]; por. Falski 2020, 57-60; por. Górski 2018, 5-21.

59 Art. 10 ust. 1 KPP. 
szerszy niż w EKPC i w MPPOiP. Niektórzy autorzy widzą tu istotną różnicę w definiowaniu zakresu wolności religijnej w obu dokumentach ${ }^{60}$. Zauważyć jednak należy, że jakkolwiek klauzula sumienia nie doczekała się w EKPC osobnej regulacji, to jednak została wyinterpretowana orzeczniczo z art. 9 EKPC i obecnie uznaje się, iż prawo do sprzeciwu sumienia wynika $\mathrm{z}$ art. $9 \mathrm{EKPC}^{61}$.

Art. 10 KPP nie posiada własnej szczegółowej klauzuli limitacyjnej odnośnie do prawa uzewnętrzniania przekonań religijnych. Nie oznacza to jednak, że omawiana wolność nie jest w KPP ograniczana.

W dniu 24 czerwca 2013 r. Rada Unii Europejskiej przyjęła Wytyczne $U E \mathrm{w}$ sprawie propagowania i ochrony wolności religii lub przekonań, które zawierają ogólne - obecne również, jak wykazano wyżej, w tradycji interpretacyjnej art. 9 ust. 2 EKPC i art. 18 ust. 3 MPPOiP - wskazanie, że ograniczenia wolności uzewnętrzniania religii lub przekonań muszą być interpretowane w sposób ścisły ${ }^{62}$. Powiązanie praw zawartych w art. 10 KPP z mechanizmami limitacyjnymi zawartymi w EKPC i MPPOiP ma swoje głębokie traktatowe uzasadnienie.

Art. $52 \mathrm{KPP}$, stanowiąc w ust. 1 ogólne zasady ograniczania wszelkich praw i wolności uznanych w KPP, w ust. 3 odnosi się bezpośrednio do EKPC i stanowi: ,w zakresie, w jakim niniejsza Karta zawiera prawa, które odpowiadają prawom zagwarantowanym w europejskiej Konwencji o ochronie praw człowieka i podstawowych wolności, ich znaczenie i zakres są takie same jak praw przyznanych przez tę konwencję". W tym samym przepisie znajduje się jednak zastrzeżenie, że: ,niniejsze postanowienie nie stanowi przeszkody, aby prawo Unii przyznawało szerszą ochronę". Przepis ten przekłada się praktycznie na rozumienie art. $10 \mathrm{KPP}$. W ogłoszonych razem z KPP w Dzienniku Urzędowym UE Wyjaśnieniach dotyczacych Karty Praw Podstawowych czytamy, że „prawo zagwarantowane w ustępie 1 odpowiada prawu zagwarantowanemu w art. 9 EKPC

60 Kamiński 2020, 2,2-2,3.

${ }_{61}$ Por. wyrok Wielkiej Izby ETPC z dnia 7 lipca 2011 r., Bayatyan przeciwko Armenii, skarga nr 23459/03, w: Nowicki, Marek Antoni. 2012. Europejski Trybunat Człowieka. Wybór orzeczeń: LEX/el, 2012, 360; por. Bielecki 2016, 124-125; Piechowiak 2003, 9-10.

62 Rada Unii Europejskiej, Wytyczne w sprawie propagowania i ochrony wolności religii lub przekonań (24 czerwca 2013 r.), COHOM 133 COPS 250 PESC 774 FREMP 91, dalej: Wytyczne. 
i zgodnie z art. 52 ust. 3 KPP UE ma takie samo znaczenie i zakres. Dlatego też, ograniczenia powinny uwzględniać artykuł 9 ust. 2 europejskiej Konwencji o ochronie praw człowieka i podstawowych wolności"63. Wyjaśnienia nie są prawnie wiążące, jednak wyznaczając linię interpretacyjną art. $10 \mathrm{KPP}$ wpisują ją w kontekst doktrynalno-orzeczniczej interpretacji mechanizmów limitacyjnych w zakresie prawa do uzewnętrzniania przekonań religijnych art. 9 EKPC oraz art. 18 ust. 3 MPPOiP ${ }^{64}$.

Każda ingerencja dokonana na mocy KPP musi realizować zatem potrójny test (legalności, celowości, konieczności) zawarty w art. 9 ust. 2 EKPC $^{65}$. Autorzy Wyjaśnień, komentując przepis art. 52 ust. 3 KPP doprecyzowują, że przyjęcie w KPP ograniczeń, jakie przewiduje EKPC „oznacza w szczególności, że ustawodawca przy określaniu ograniczeń tych praw musi przestrzegać takich norm jakie są określone na mocy szczegółowych ustaleń dotyczących ograniczeń, zawartych w europejskiej Konwencji praw człowieka i podstawowych wolności, które są w związku z tym stosowane w odniesieniu do praw objętych tym ustępem. Nie ma to wpływu na autonomię prawa Unii i Trybunału Sprawiedliwości Unii Europejskiej"66.

Owa autonomia unijnego porządku musi być brana pod uwagę w implementacji mechanizmów limitacyjnych prawa do uzewnętrzniania przekonań religijnych EKPC na gruncie prawa i orzecznictwa unijnego. Analizując prawną naturę specyfiki tych odniesień zauważyć należy, że wszystkie państwa członkowskie UE są stronami EKPC. Traktat o UE (wersja skonsolidowana 2016 r.) stanowi w art. 6 ust. 3, że prawa podstawowe zagwarantowane w EKPC stanowią część prawa UE jako ogólne zasady prawa, a TSUE odwołuje się do orzecznictwa ETPC ${ }^{67}$. Nie ulega zatem

63 Explanations relating to the Charter of Fundamental Rights (2007/C 303/02), Official Journal of the European Union, C 303 of 14 December 2007, „Explanation on article 10 - Freedom of thought, conscience and religion", dalej: Wyjaśnienia.

64 Zanghì 2013, 313-316, 380-383.

65 Kamiński 2020, 2,2.

${ }^{66}$ Wyjaśnienia, „Explanation on article 52 - Scope and interpretation of rights and principles".

${ }^{67}$ Consolidated versions of the Treaty on European Union and the Treaty on the Functioning of the European Union (Consolidated version 2016), Official Journal of the European Union 202, 7.6.2016, art. 6, 3; por. Zanghì 2013, 376-377; Wieruszewski 2008, 53-58; Ottavio Marzocchi, The protection of fundamental rights in the European Union, https:// 
wątpliwości, że orzecznictwo ETPC stanowi ważną część acquis w dziedzinie praw podstawowych (termin bliższy unijnej tradycji) ${ }^{68}$. Traktat o UE w art. 6 ust. 2 jednak, stanowiąc o - iluzorycznym jak dotąd - przystąpieniu UE do EKPC zastrzega, że ,nie narusza to kompetencji Unii określonych w Traktatach"69.

Jak przyjęli autorzy Wyjaśnień, standard wynikający z KPP odpowiada standardowi EKPC i w żaden sposób nie może być od niego niższy, ale może być od niego wyższy, to znaczy gwarantować wyższy stopień ochrony. W odniesieniu do mechanizmu limitacji prawa do wolności uzewnętrzniania przekonań religijnych w doktrynie wskazuje się, że możliwa jest zatem sytuacja, iż TSUE wyjdzie poza stanowisko ETPC, akceptując np. pogląd wyrażony w rozstrzygnięciach KPCz ONZ, a więc pogląd wyinterpretowany z przepisu art. 18 ust. $3 \mathrm{MPPOiP}^{70}$.

\section{PODSUMOWANIE}

W niniejszym artykule, którego przedmiotem były mechanizmy limitacji prawa do wolności uzewnętrzniania przekonań religijnych w EKPC, MPPOiP i KPP, poddano analizie przepisy art. 9 ust. 2 EKPC oraz art. 18 ust. 3 MPPOiP - zawierające szczegółowe klauzule limitacyjne prawa do uzewnętrzniania przekonań religijnych, jak również art. $10 \mathrm{KPP}$, który mechanizmy limitacyjne omawianego prawa, zawarte $\mathrm{w}$ jego treści prawa „zapożycza” - choć nie bez zastrzeżeń z EKPC. Limitacja przedmiotowego prawa, stosując ścisłą interpretację przepisów limitacyjnych, może dotyczyć tylko realizacji tego prawa forum externum, a jego forum internum jest nielimitowalne.

Odnośnie do klauzuli limitacyjnej $\mathrm{z}$ art. 9 ust. 3 EKPC stwierdzono, że jest ona jedną z pięciu (obok klauzul w art. 8-11 EKPC oraz art. 2 Protokołu IV do EKPC) szczegółowych (odnoszącą się do możliwości

www.europarl.europa.eu/RegData/etudes/BRIE/2019/621911/IPOL_BRI(2019)621911_ EN.pdf [dostęp: 02.06.2021].

68 Kubala 2015, 205-206.

${ }^{69}$ Consolidated versions of the Treaty on European Union and the Treaty on the Functioning of the European Union, art. 6 ust. 2 .

70 Kamiński 2020, 35, 9. 
ograniczenia konkretnego prawa) klauzul, realizujących założenia teoretyczne tak zwanej pełnej klauzuli ograniczającej, choć posiada nieco uboższy katalog celów prawowitych w odniesieniu do pozostałych. Jednym z tych założeń teoretycznych jest specyficzna budowa, wyrażająca się w trójczłonowej konstrukcji klauzuli limitacyjnej, na którą składają się tak zwane testy (test: legalności, konieczności, celowości) - przesłanki, których jednoczesne występowanie bada ETPC, orzekając o dopuszczalności zaskarżanego ograniczenia. Podobną budowę posiada klauzula limitacyjna zawarta w art. 18 ust. 3 MPPOiP, dokumencie normatywnym, w redakcji którego oczywistym punktem odniesienia była EKPC. Obie klauzule posiadają taki sam katalog celów prawowitych, których występowanie brane jest pod uwagę w przeprowadzanym przez ETPC teście celowości. Różniącą obie klauzule jest inna koncepcja konieczności (badanej przez ETPC w teście konieczności), w EKPC motywowanej wartościami państwa demokratycznego, a w MPPOiP bezpośrednio odnoszona do katalogu celów podstawowych. Z przeprowadzonych analiz wynika, że klauzula konieczności wartości państwa demokratycznego z art. 9 EKPC, której zadaniem miała być obiektywizacja oceny dopuszczalności poprzez odniesienie do wartości państwa demokratycznego, w gruncie rzeczy nie może dziś takiej roli już odgrywać, wobec coraz mocniej zaznaczającej się polaryzacji tego typu odniesień. Bardziej uniwersalistycznym i przez to nośnym jest odniesienie kryterium konieczności bezpośrednio do konkretnych celów prawowitych - jak w art. 18 MPPOiP. Praktyczną konsekwencją tego stanu rzeczy są coraz bardziej widoczne różnice w stanowiskach zajmowanych przez ETPC i KPCz ONZ (1. Protokół fakultatywny do MPPOiP wprowadził możliwość skargi indywidualnej do KPCz ONZ) odnośnie do oceny dopuszczalności ograniczeń wolności manifestowania przekonań religijnych, w konkretnych stanach faktycznych.

W odniesieniu do celów prawowitych należy zauważyć, że niewątpliwą wartością katalogu celów prawowitych w MPPOiP z art. 18 ust. 3 jest jego jednolita wykładnia zawarta przede wszystkim - na poziomie ogólnym - w Zasadach, a konkretnie w odniesieniu do art. 18 ust. 3 - w Komentarzu, podczas gdy wykładnia celów prawowitych z art. 9 ust. 2 EKPC skazana jest na „kapryśność” wykładni dynamicznej ETPC. Wszystko to sprawia, że klauzula limitacyjna zawarta w art. 18 ust. 3 MPPOiP jawi się jako bardziej uniwersalistyczna, a dzięki bardziej jednorodnej wykładni 
daje mniejsze pole do nadużyć w ocenie zasadności ograniczeń wprowadzanych w konkretnym stanie faktycznym.

Art. 10 KPP, który nie zawiera własnej klauzuli limitacyjnej, czerpie z zastrzeżeniem specyfiki normatywnych odniesień obu porządków - znaczenie i zakres z EKPC, a co za tym idzie również z tradycji orzeczniczej ETPC. Specyfika normatywnych odniesień obu porządków znaczona jest jednak zastrzeżeniem autonomii prawa UE i TSUE, która w założeniu ma zapewnić wyższy niż konwencyjny poziom ochrony praw człowieka, co uprawdopodabnia sytuację, że TSUE wyjdzie poza stanowisko ETPC, akceptując np. pogląd wyrażony w rozstrzygnięciach KPCz ONZ.

\section{BIBLIOGRAFIA}

Bielecki, Marek. 2016. „Odmowa pełnienia służby wojskowej przez świadków Jehowy jako realizacja klauzuli sumienia. Uwarunkowania prawno-historyczne". Studia z Prawa Wyznaniowego 19: 107-128.

Garlicki, Leszek. 2010. „Artykuł 9. Wolność myśli, sumienia i wyznania”. W: Konwencja o Ochronie Praw Człowieka i Podstawowych Wolności. Tom 1. Komentarz do artykułów 1-18, red. Leszek Garlicki, 550-582. Warszawa: C.H. Beck.

Falski, Jacek. 2020. „Zagwarantowanie warunków życia razem - element ochrony praw i wolności innych jako nowy wymóg demokratycznego społeczeństwa (na podstawie wyroku Wielkiej Izby ETPC z 1 lipca 2014 w sprawie S.A.S. v. Francja)". Przeglad Sejmowy 1: 45-64.

Górski, Marcin. 2018. „Sędziowski aktywizm ETPC a deficyty strukturalne systemu Europejskiej Konwencji o Ochronie Praw Człowieka i Podstawowych Wolności”. Polski Rocznik Praw Człowieka i Prawa Humanitarnego 8: 5-21. Jasudowicz, Tadeusz. 1997. „Studium substancjalnych przesłanek dopuszczalności środków derogacyjnych". W: Prawa czlowieka w sytuacjach nadzwyczajnych ze szczególnym uwzględnieniem prawa i praktyki polskiej, red. Tadeusz Jasudowicz, 45-82. Toruń: TNOiK.

Jasudowicz, Tadeusz. 2012. „Test celowości w funkcjonowaniu mechanizmu limitacji korzystania z praw człowieka w systemie EKCP”. Polski Rocznik Praw Człowieka i Prawa Humanitarnego 3: 109-133.

Kamiński, Ireneusz C. 2020. „Artykuł 10 Wolność myśli sumienia i religii”. W: Karta Praw Podstawowych Unii Europejskiej. Komentarz 2020, red. Andrzej Wróbel, 1-57. Warszawa: C.H. Beck [legalis.pl]. 
Kędzia, Zdzisław. 2018. „70 lat Powszechnej Deklaracji Praw Człowieka - Pomnik czy żywy dokument?". Ruch Prawniczy, Ekonomiczny i Socjologiczny 4: $5-23$.

Księżniakiewicz, Malwina. 2012. „Stosowanie Karty Praw Podstawowych Unii Europejskiej: Protokół brytyjski i Sprawozdania ze stosowania KPP UE”. Rocznik Integracji Europejskiej 6: 333-348.

Kubala, Maciej. 2015. „Ochrona wolności sumienia w artykule 10 Karty Praw Podstawowych”. W: Aktualne problemy wolności myśli, sumienia $i$ wyznania, red. Piotr Stanisz, Aneta Abramowicz, Michał Czelny, Marta Ordon, Michał Zawiślak, 205-212. Lublin: Wydawnictwo KUL.

Latos, Bartłomiej. 2008. Klauzula derogacyjna i limitacyjna w Europejskiej Konwencji o ochronie praw człowieka i podstawowych wolności. Warszawa: Wydawnictwo Sejmowe.

Mizerski, Rafał. 2009. Test legalności w Europejskiej Konwencji Praw Człowieka. Warszawa: Wydawnictwo Sejmowe.

Mizerski, Rafał. 2013. „Podstawy obowiązku ustanowienia krajowych gwarancji proceduralnych w systemie Europejskiej Konwencji Praw Człowieka”. Polski Rocznik Praw Człowieka i Prawa Humanitarnego 4: 69-106.

Mojski, Wojciech. 2014. „Ochrona wolności wypowiedzi w świetle uwag ogólnych nr 34 Komitetu Praw Człowieka”. Studia Iuridica Lublinensia 22: 589-602.

Murdoch, Jim. 2012. Ochrona prawa do wolności myśli, sumienia i wyznania w Europejskiej Konwencji o Ochronie Praw Człowieka i Podstawowych Wolności. Strasburg: Rada Europy.

Piechowiak, Marek. 2003. „Aksjologiczne podstawy Karty Praw Podstawowych”. Studia Prawnicze 1: 5-30.

Piechowiak, Marek. 2009. „Klauzula limitacyjna a nienaruszalność praw i godności”. Przeglad Sejmowy 2: 55-77.

Radajewski, Mateusz. 2015. „Derogacja praw i wolności w sytuacjach nadzwyczajnych w międzynarodowych systemach ochrony praw człowieka". W: Międzynarodowa ochrona praw człowieka - współczesne problemy na świecie, red. Mariusz Jabłoński, Tomasz Jurczyk, Patryk Guttierez, 129-141. Wrocław: Wydział Prawa, Administracji i Ekonomii.

Rozner, Monika. 2002. „Prawo do wolności religijnej w Europejskiej Konwencji Praw Człowieka z 1950 r." Studia z Prawa Wyznaniowego 5: 111-135.

Sobczak, Jacek, Maria Gołda-Sobczak. 2012. „Wolność sumienia i wyznania jako prawo człowieka". Annales Universitatis Mariae Curie-Skłodowska Sectio K 19 (1): 27-65.

Skrzydło, Jacek. 2013. „Nadużycie przez państwo klauzuli limitacyjnej - refleksje na tle spraw dotyczących artykułu 18 Europejskiej Konwencji Praw 
Człowieka". Artykuły Wydziału Prawa i Administracji Uniwersytetu Łódzkiego, red. Anna Wyrozumska, 1-17. Łódź: Seria wydawnicza Katedry Europejskiego Prawa Konstytucyjnego.

Szuniewicz, Marta. 2016. Ochrona bezpieczeństwa państwa jako przesłanka ograniczenia praw $i$ wolności jednostki $w$ świetle europejskiej konwencji praw człowieka. Warszawa: C.H. Beck.

Warchałowski, Krzysztof. 2002. „Wolność uzewnętrzniania religii i przekonań religijnych w europejskiej Konwencji Praw Człowieka". Kwartalnik Prawa Publicznego 1-2: 189-212.

Wieruszewski, Roman. 2008. „Rola i znaczenie Karty Praw Podstawowych Unii Europejskiej dla Ochrony Praw Człowieka". Przegląd Sejmowy 2: 41-59.

Wieruszewski, Roman. 2012. „Artykuł 18. Wolność myśli, sumienia i religii”. W: Międzynarodowy Pakt Praw Obywatelskich (osobistych) i Politycznych. Komentarz, red. Roman Wieruszewski, 419-460. Warszawa: Wolters Kluwer. Wojtyczek, Krzysztof. 1999. Granice ingerencji ustawodawczej w sferę praw człowieka w Konstytucji RP. Kraków: Zakamycze.

Zakolska, Joanna. 2005. „Problem klauzuli ograniczającej korzystanie z praw i wolności człowieka w pracach konstytucyjnych, w poglądach doktryny i orzecznictwa Trybunału Konstytucyjnego". Przeglad Sejmowy 5: 11-30.

Zanghì, Claudio. 2013. La protezione dei diritti dell'uomo. Torino: G. Giappichelli. 
